Клюсов О.М.

\title{
Динаміка та особливості смертності, захворюваності на злоякісні новоутворення в Україні, зокрема з їх локалізацією в прямій кишці
}

\author{
Національна медична академія післядипломної освіти імені П.Л. Шупика, м. Київ, Україна \\ kmkoc.kyiv@gmail.com
}

\begin{abstract}
Клюсов А.Н.
Динамика и особенности смертности, заболеваемости злокачественными новообразованиями в Украине, в частности с их локализацией в прямой кишке

Национальная медицинская академия последипломного образования имени П.Л. Шупика, г. Киев, Украина
\end{abstract}

Klusov O.M.

Dynamics and features of mortality, incidence of malignant new growths in Ukraine, in particular with their localization in the rectum

National Medical Academy of Postgraduate Education named after P.L. Shupik, Kyiv, Ukraine

\section{Встуі}

Вивчення проблем, пов'язаних із виникненням, розвитком, профілактикою, діагностикою, лікуванням новоутворень, зокрема злоякісних, в науковій медичній літературі приділяється багато уваги, є так дослідження і серед фундаментальних і прикладних тем провідних науково-дослідних вітчизняних установ [1-6]. Новоутворення тривалий час посідають одне з основних місць в структурі смертності населення в Україні, проблема поширення злоякісних новоутворень $\epsilon$ актуальною і для країн Європейського регіону [7-11]. Вивчення проблеми зростання поширеності злоякісних новоутворень, зокрема 3 локалізацією в прямій кишці, 3 роками не втрачає своєї актуальності, адже за даними офіційної статистики як серед чоловіків, так і серед жінок, у більшості випадків діагноз злоякісного новоутворення в Україні встановлюється в розвиненій та/або пізній стадії прогресування хвороби.

Метою дослідження стало вивчення регіональних особливостей основних статистичних показників та значення смертності, захворюваності на злоякісні новоутворення, зокрема 3 локалізацією в прямій кишці, серед населення України та в м. Києві (в розрізі їі основних адміністративних територій (районів) на основі проведення аналізу даних офіційної статистики в порівнянні 3 описаними в наукових публікаціях тенденціями.

\section{Матеріали та методи}

Матеріалами для дослідження слугували дані офіційної статистичної звітності закладів охорони здоров'я областей України, районів міста Києва за формами №7 та №20 Центру медичної статистики MO3
України та Головного управління охорони здоров'я Київської міської державної адміністрації. В дослідженні використані методи соціальної медицини, а саме бібліосемантичний, медико-статистичний, аналітикосинтетичний та контент-аналізу, з їх допомогою вивчалися описані в наукових публікаціях тенденції смертності, захворюваності на злоякісні новоутворення на предмет ïх порівняння з регіональними особливостями динаміки аналогічних показників серед населення мегаполісу, яким обрано місто Київ.

\section{Результати дослідження та їх обговорення}

За результатами проведеного дослідження за період 2011-2017 pp. виявлено зменшення показника захворюваності на злоякісні новоутворення (з 370,7 в 2011 р. до 354,8 на 100 тис. населення в 2017 р, або -4,25\%) (рис. 1), яке найвищими темпами відбувалося в Одеській (3 386,0 в 2011 р. до 296,0 в 2017 р., або -23,32\%), Чернівецькій (з 291,8 в 2011 р. до 243,9 в 2017 р., або $-16,42 \%$ ), Запорізькій (з 442,9 в 2011 р. до 379,1 в 2017 р., або $-14,41 \%$ ) та Рівненській (з 284,9 в 2011 р. до 255,8 в 2017 р., або -10,21\%) областях.

Відстеження гендерних відмінностей зменшення захворюваності на злоякісні новоутворення в Україні не виявило суттєвих відмінностей. Серед чоловіків показник змінився 3382,2 в 2011 р. до 364,8 в 2017 р., або $-4,55 \%$, серед жінок, - з 360,9 в 2011 р. до 346,1 в 2017 р., або $-4,1 \%$ (рис. 2). Темпи зменшення стандартизованих (за українським стандартом) показників захворюваності на злоякісні новоутворення виявилися ще інтенсивнішими (3 345,2 в 2011 р. до 307,5 в 2017 р., або -10,92\%), що підтверджує вплив «постаріння» населення на формування значення показника. 


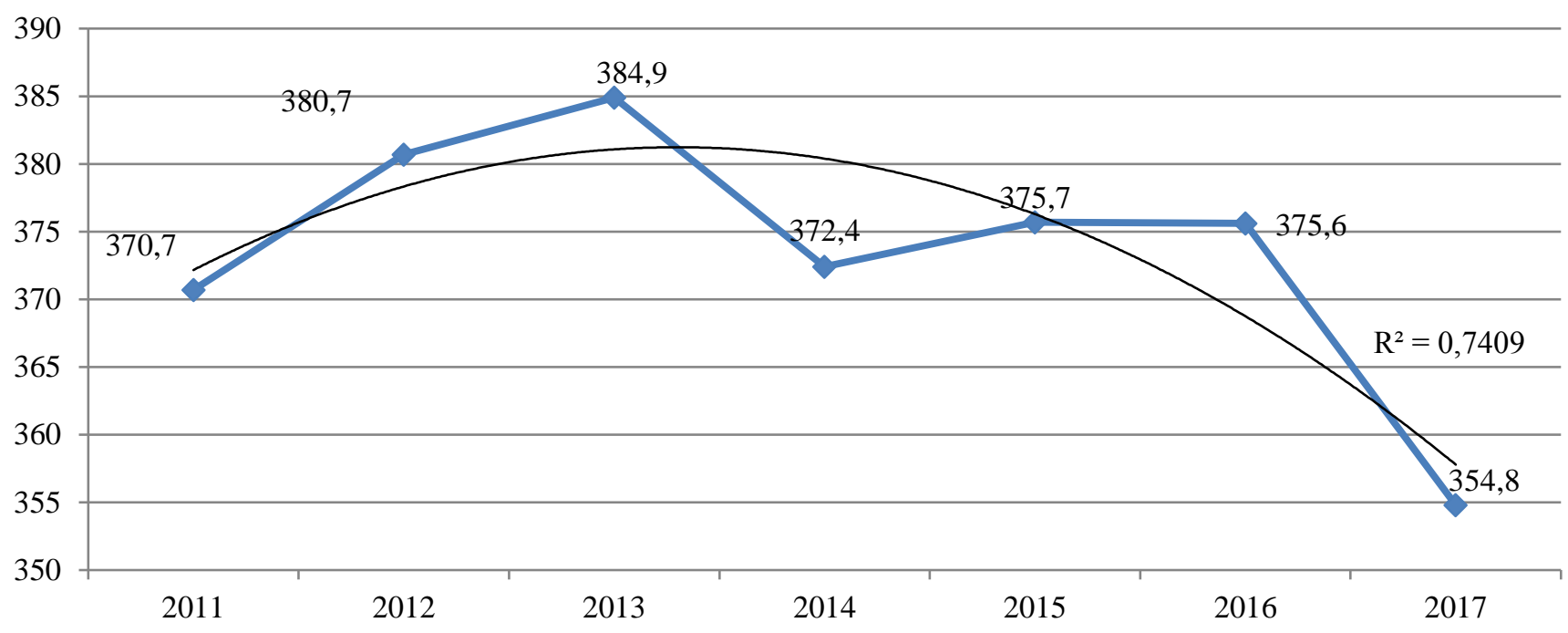

Рис. 1. Динаміка захворюваності на злоякісні новоутворення в Україні за 2011-2017 рр. (на 100 тис. населення)

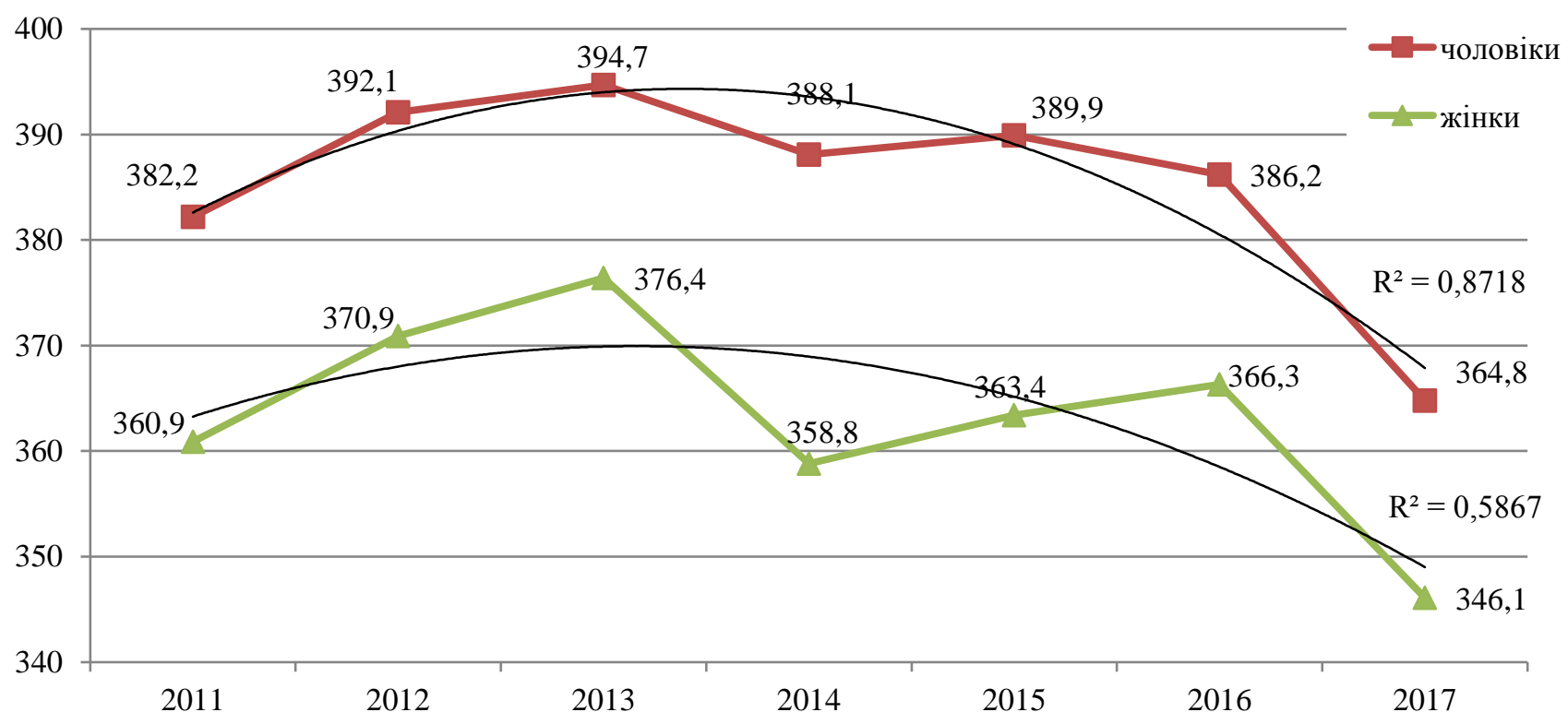

Рис. 2. Динаміка захворюваності на злоякісні новоутворення чоловіків та жінок в Україні за 2011-2017 pр. (на 100 тис. населення)

Виявлені в місті Києві та Київській області регіональні особливості захворюваності на злоякісні новоутворення зумовлені переважанням захворюваності на рак серед жінок, особливо суттєвою є різниця в місті Києві (355,4 серед чоловіків проти 395,2 серед жінок).

Переважають жінки і серед зростаючого в Україні (з 2227,2 в 2011 р. до 2622,5 на 100 тис. населення в 2017 р., або $+17,7 \%$ ) контингенту осіб, які перебувають під спостереженням з приводу злоякісного новоутворення. Суттєво переважає зростаюча кількість жінок (з 2 686,7 до 3183,5 на 100 тис. населення, або +18,5\%) проти зростаючої порівняно меншими темпами кількості чоловіків (з 1 690,6 до 1976,0 на 100 тис. населення, або $+16,9 \%$ ) (рис. 3 ).

Динаміка відсотку виявлення злоякісних новоутворень під час профілактичних оглядів за період дослідження виявила його поступове зменшення (з 29,7\% в 2011 р. до 28,0\% в 2017 р., або -5,7\%) при найвищих його значеннях в м. Києві $(58,3 \%)$ та Миколаївській $(42,7 \%)$ області.

Невеликий відсоток виявлення злоякісних новоутворень під час профілактичних оглядів в Одеській $(8,9 \%)$ області засвідчує наявність суттєвих прогалин в профілактичній роботі медичної служби в області. 


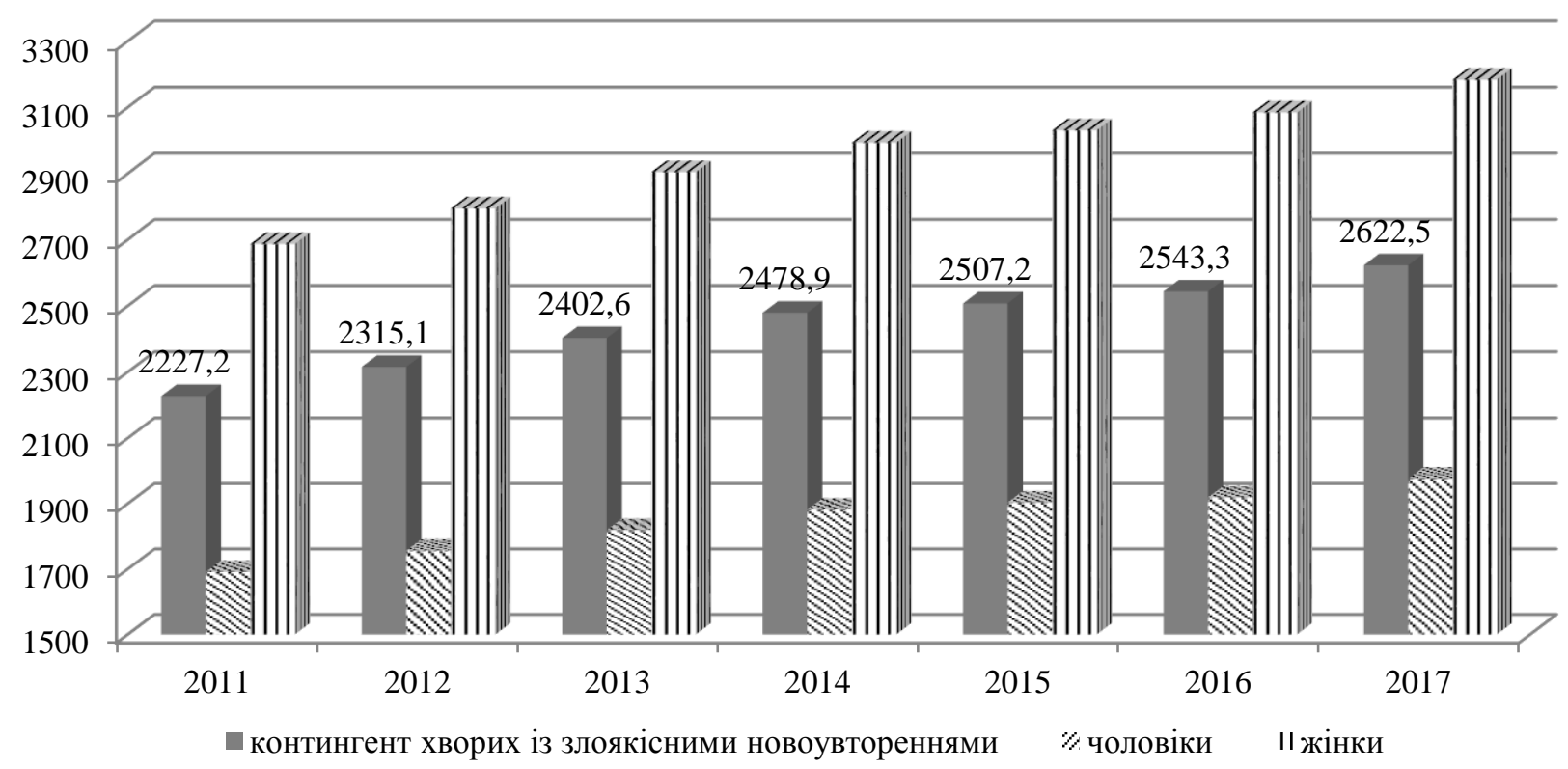

Рис. 3. Динаміка контингенту осіб із злоякісними новоутвореннями в Україні з розподілом за статтю за 2011-2017 pp. (на 100 тис. населення)

Разом із тенденціями до зменшення відсотку злоякісних новоутворень, виявлених при профілактичних оглядах, зростає відсоток встановлення вперше діагнозу онкологічного захворювання в пізній (IV) його стадії (рис. 4). Якщо в 2011 р. відсоток встановлення вперше діагнозу злоякісного новоутворення в IV ст. лише в трьох областях країни перевищував 20,0\% (Херсонська $(24,2 \%$ ), Полтавська $(23,5 \%)$, Черкаська $(20,0 \%)$, то за підсумками 2017 р. до цих же областей $(23,7 \% ; 22,4 \% ; 22,1 \%$ відповідно) додалися ще 9 областей (Чернівецька $(25,2 \%)$, Херсонська $(23,7 \%)$, Одеська $(22,4 \%)$, Чернігівська $(22,1 \%)$, Закарпатська $(22,0 \%)$, Житомирська $(21,8 \%)$,
Луганська (21,5\%), Івано-Франківська $(21,3 \%)$, Київська $(20,4 \%)$ та Тернопільська (20,3\%) області), що і зумовило зростання середнього по Україні відсотку встановлення вперше діагнозу злоякісного новоутворення в IV стадії з $14,7 \%$ в 2011 р. до 17,0\% в 2017 р. (зростання на 15,6\%).

В структурі захворюваності на злоякісні новоутворення за локалізацією серед чоловіків переважає рак трахеї, бронхів, легень (17,5\% в 2011 р. та 15,8\% в 2017 р.). За період дослідження на друге місце в 2017 р. (10,7\%) 3 третього (в 2011 р. 9,5\%) перемістився рак простати. На третьому, - немеланомні злоякісні новоутворення шкіри, які поступилися раку простати (в 2017 р. 9,9\%).

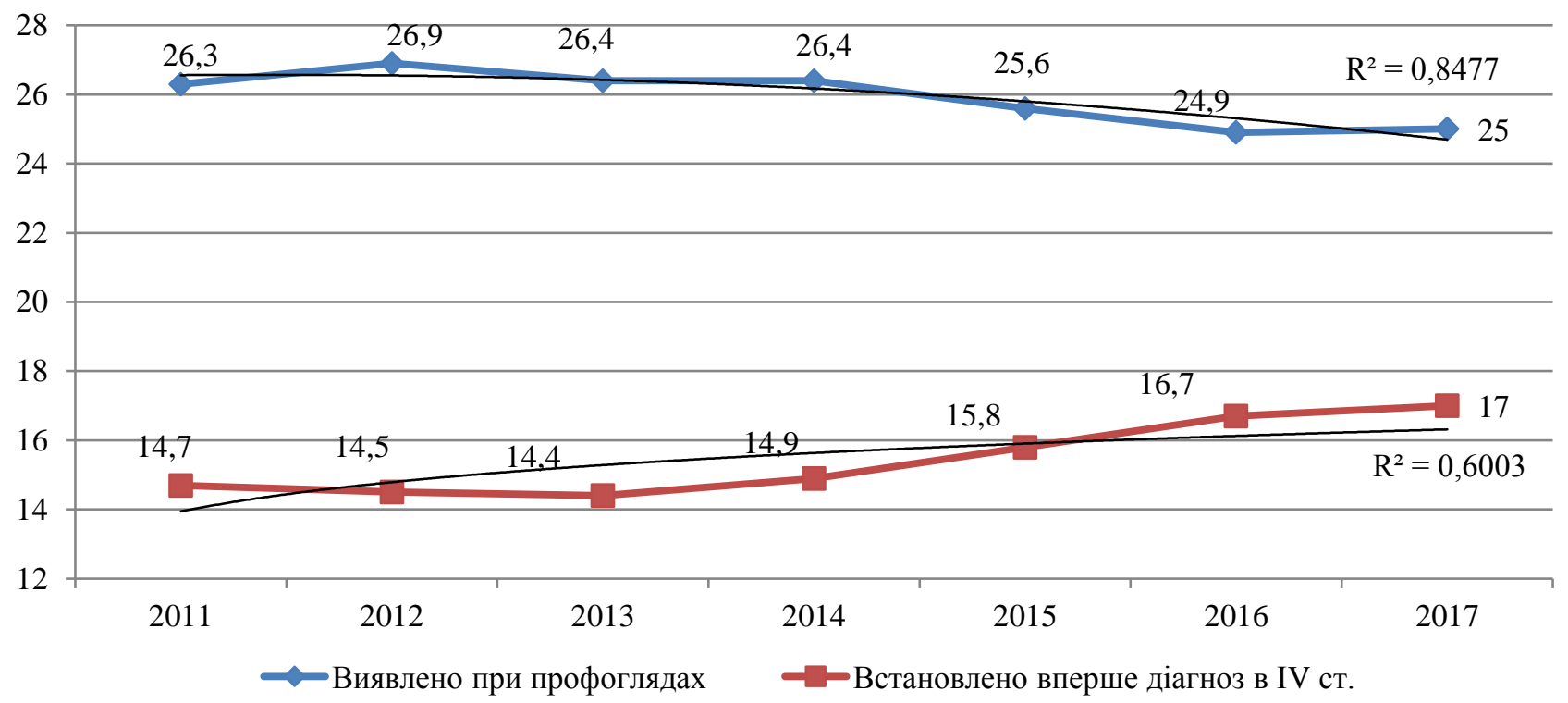

Рис. 4. Динаміка відсотків виявлення злоякісних новоутворень під час профілактичних обстежень та встановлення вперше діагнозу в IV ст. захворювання (в \%, за період 2011-2017 pp.) 
Незмінно за ранговими місцями, але із коливаннями в значеннях залишилися: на 4-му місці - рак шлунка (8,4\% в 2011 р., 7,4\% в 2017 р.); на 5-му - ободової кишки (6,2\% в 2011 р., 6,4\% в 2017 р.); на 6-му - прямої кишки (6,1\% в 2011 р., 6,1\% в 2017 р.); на 7-му - сечового міхура (5,4\% в 2011 р., 5,5\% в 2017 р.).

Гендерні особливості структури захворюваності на злоякісні новоутворення у жінок проявилися зростанням питомої ваги локалізації злоякісного новоутворення в молочній залозі (з 19,6\% в 2011 р. до 20,3\% в 2017 р.). На другому залишилися немеланомні злоякісні новоутворення шкіри (12,8\% в 2011 р. та 12,6\% в 2017 р.), на 3-му - рак тіла матки $(8,6 \%$ в 2011 р. та $9,1 \%$ в 2017 р.), на 4-му - ободової кишки $(6,6 \%$ в 2011 р. та $6,5 \%$ в 2017 р.), на 5-му - шийки матки (6,0\% в 2011 р., 5,9\% в 2017 р.), на 6-му - прямої кишки (5,2\% в 2011 р., 4,9\% в 2017 р.), на 7-му місці в 2011 р. був рак шлунка $(5,1 \%$ в 2011 р., 4,5\% в 2017 р.), який в 2017 р. поступився місцем раку яєчників (4,9\% в 2011 р., 4,8\% в 2017 р.).

Вікова структура захворюваності на злоякісні новоутворення чоловіків представлена переважно віковими категоріями: 55-64 роки $(30,4 \%), 65-74$ роки $(29,2 \%), 30-54$ роки $(17,8 \%)$.

Вікова структура захворюваності жінок на злоякісні новоутворення представлена віковими категоріями: 5564 роки $(26,0 \%), 30-54$ роки $(24,9 \%), 65-74$ роки $(24,6 \%)$. Зазначена картина може свідчити про більш пізне звернення в медичні заклади саме чоловіків, що передбачає і пізніше встановлення діагнозу онкологічного захворювання, а отже, потребує медико-організаційного втручання 3 урахуванням виявлених гендерних особливостей.

В структурі захворюваності на злоякісні новоутворення серед населення України, їх локалізація в прямій кишці, як серед чоловіків, так і серед жінок, незмінно (за період 2011-2017 рр.) посідає шосте рангове місце $(6,1 \%$ серед чоловіків, $4,9 \%$ серед жінок). Одночасно, локалізація злоякісного новоутворення в прямій кишці стає причиною смерті 6,3\% чоловіків та 6,6\% жінок, що вивело рак цієї локалізації на п'яте рангове місце у чоловіків та четверте рангове місце серед жінок в структурі причин смертності від злоякісних новоутворень за підсумками 2017 року. У віковій групі чоловіків 5574 роки смертність від раку рак прямої кишки посіла четверте рангове місце $(6,3 \%)$, а у віковій групі 75 років і старше, - П'яте серед чоловіків $(7,8 \%)$ та четверте серед жінок $(8,3 \%)$.

Захворюваність на рак, зокрема 3 локалізацією в прямій кишці в Україні поступово зменшується (з 20,7 в 2011 р. до 19,4 в 2017 р., або -6,28\%), як серед чоловіків (з 23,3 в 2011 р. до 22,3 в 2017 р., або $-4,3 \%$ ), так і серед жінок (з 21,1 в 2011 р. до 19,3 в 2017 р., або -8,5\%). Щорічно реєструється більше семи тисяч нових випадків захворювань на рак прямої кишки. Разом із зниженням захворюваності на рак прямої кишки зменшується відсоток встановлення діагнозу цього захворювання під час профілактичних оглядів (з 20,2 в 2011 р. до 18,2 в 2017 р., або -9,9\%). Позитивно найвищим цей відсоток виявлено в 2017 р. в м.Києві $(54,9 \%)$, хоча є області (Херсонська $(9,6 \%)$, Волинська $(8,8 \%)$, Дніпропетровська $(6,6 \%)$, Одеська (4,3\%)), де відсоток не перевищує 10,0\%, що засвідчує наявність суттєвих прогалин в профілактичній роботі наведених областей (рис. 5).

При вивченні показників онкологічної захворюваності серед населення міста Києва навпаки були виявлені тенденції до зростання, як ії абсолютних значень (з 10017 випадків в 2011 р. до 10868 в 2017 р., або на 8,5\%), так і відносного показника на 3,96\%) (рис. 6 та 7), що підтверджено застосуванням побудови ліній тренду 3 апроксимацією та згладжуванням.

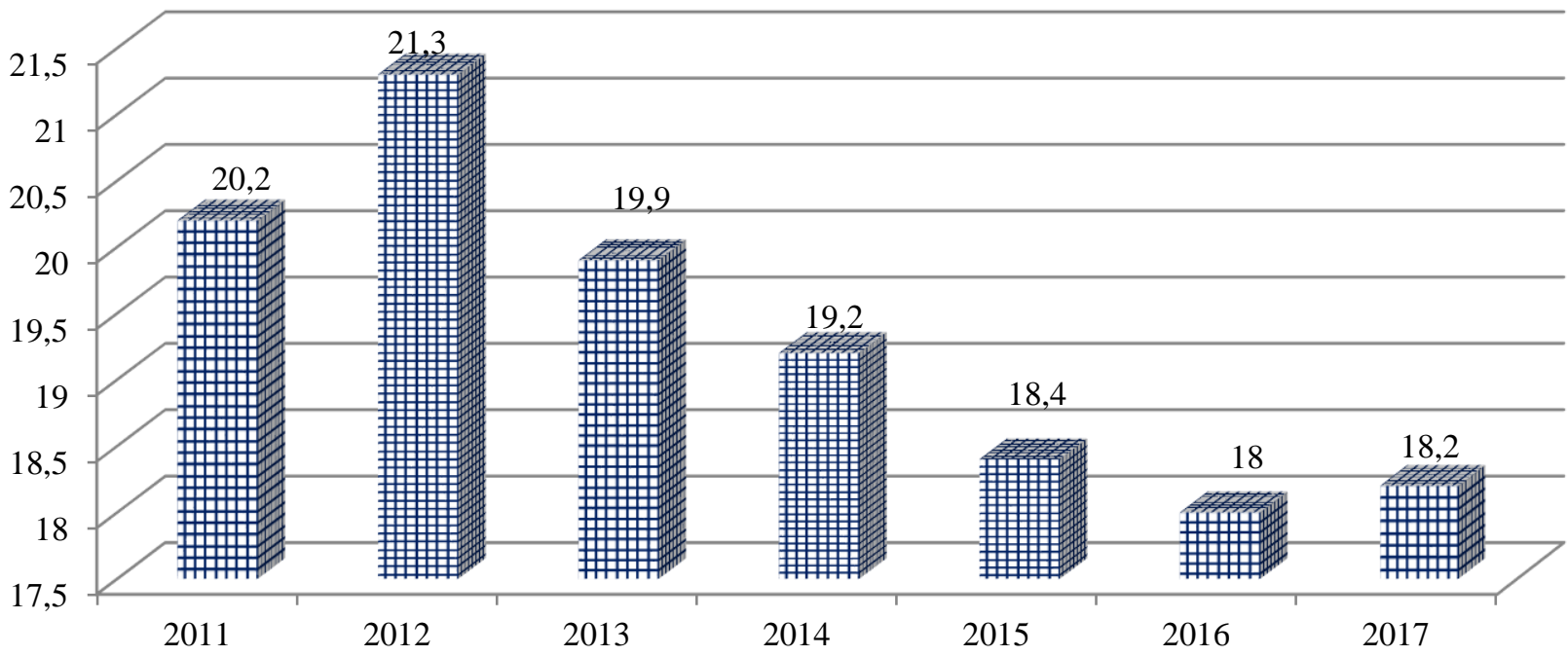

Рис. 5. Динаміка зменшення відсотку встановлення діагнозу злоякісного новоутворення прямої кишки під час профілактичного огляду (в \%, за період 2011-2017рр.). 


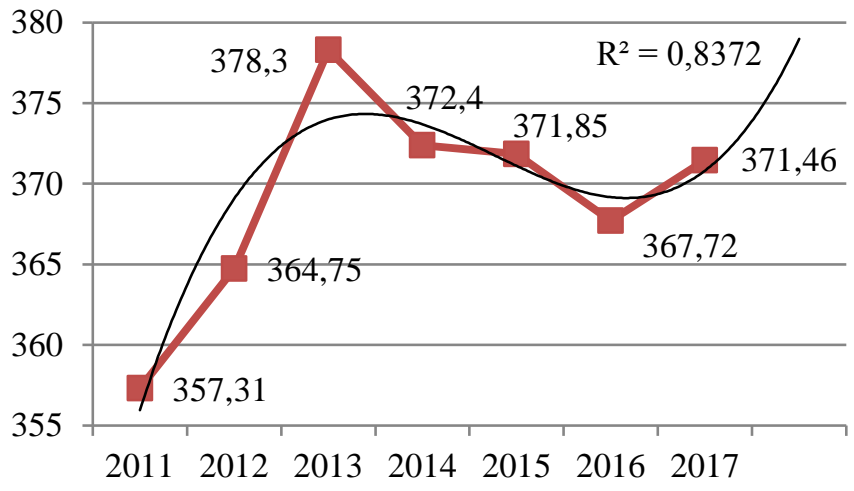

Рис. 6. Динаміка онкологічної захворюваності на 100 тис. населення м. Києва

В місті Києві щорічно вперше встановлюють діагноз онкологічного захворювання більше 10 тис. хворих (в 2011 р. 10017 ; в 2012 р. - 10 298; в 2013 р. 10788 ; в 2014 р. - 10710 ; в 2015 р. - 10763 ; в 2016 р. 10 690; в 2017 р. - 10868 випадків), попри коливання наведених абсолютних значень наявним $є$ поступове їх щорічне збільшення. Відносний показник онкологічної захворюваності в розрахунку на 100 тис. населення також зріс в більшості районів міста Києва за виключенням Печерського (-17,01\%), Подільського (-6,52\%) та Солом'янського $(-4,92 \%)$ районів.

Найвищі рівні захворюваності на онкологічну патологію за підсумками 2017 р. були виявлені в Шевченківському (427,42 на 100 тис. населення, що в абсолютних цифрах склало 1100 випадків), Дніпровському (419,82 на 100 тис. населення, що склало 1493 випадки) та Деснянському (405,65 на 100 тис. населення, що склало 1498 випадків) районах. Таким значенням показників в 2017 р. передувало поступове зростання захворюваності за період 2011-2017 рр. на 4,34\% в Шевченківському, на 7,51\% в Дніпровському та на $17,02 \%$ в Деснянському районах.

Найнижчі показники онкологічної захворюваності в 2017 році виявлені в Печерському районі (288,75 на 100 тис. населення, що склало 386 випадків в 2017 р.) 3 вираженими тенденціями до зменшення, як за період 2011-2017 pp. на -17,01\%, так і за 2016-2017 pp. на -5,65\%.

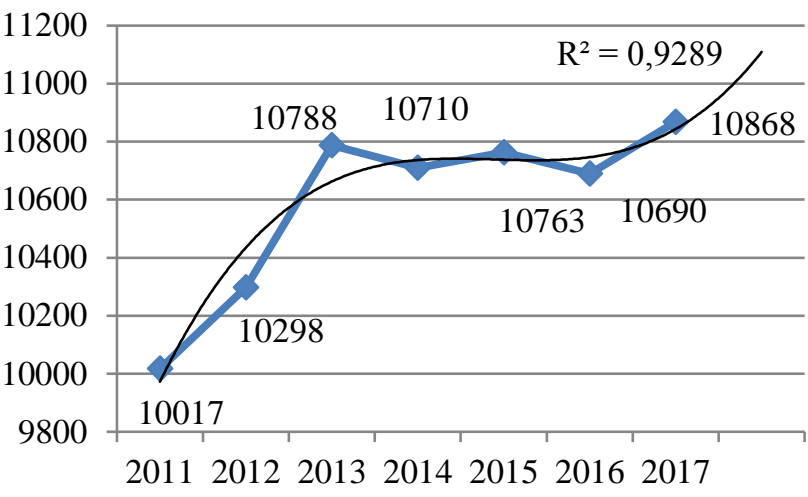

Рис. 7. Динаміка абс. значень онкологічної захворюваності в м. Києві

Різниця між крайніми значеннями показника онкологічної захворюваності в 2017 р. склала в 1,48 разу $(\mathrm{p}<0,05)$.

За підсумками 2017 року в структурі захворюваності на онкологічну патологію серед населення міста Києва за локалізацією перші рангові місця посіли: молочна залоза (86,9 на 100 тис. населення), простата $(49,4)$, шкіра $(43,3)$, тіло матки $(39,20)$, ободова кишка $(28,8)$, легені $(23,5)$, шлунок $(20,4)$, пряма кишка $(19,0)$. За період 2011-2017 рр. відмічено суттєвий приріст злоякісних новоутворень 3 локалізацією: ротова порожнина (з 6,9 в 2011 р. до 8,4 в 2017 р., або +21,74\%); шийка матки (з 14,8 до 17,8, або +20,27\%); меланома (з 9,3 до 10,9, або +17,2\%); лімфома (з 11,1 до 14,2, або +27,93\%), молочна залоза (з 76,4 до 86,9, або +13,74\%).

За період дослідження в Києві зріс контингент осіб 3 діагнозом онкологічного захворювання (з 68035 осіб в 2011 р. до 85963 особи в 2017 році), показник в розрахунку на 100 тис. населення зріс з 2426,8 в 2011 р. до 2938,1 в 2017 р., або $+21,07 \%$ (рис. 8). Найбільше пацієнтів 3 онкологічною патологією перебуває на диспансерному обліку в Дніпровському (11600 осіб), Деснянському (10842), Оболонському (10521), Святошинському (9761) районах.

Позитивно, що за період дослідження в Україні смертність від злоякісних новоутворень зменшилася 3 186,3 в 2011 р. до 173,5 на 100 тис. населення в 2017 р., або на $6,87 \%$ (рис. 9).

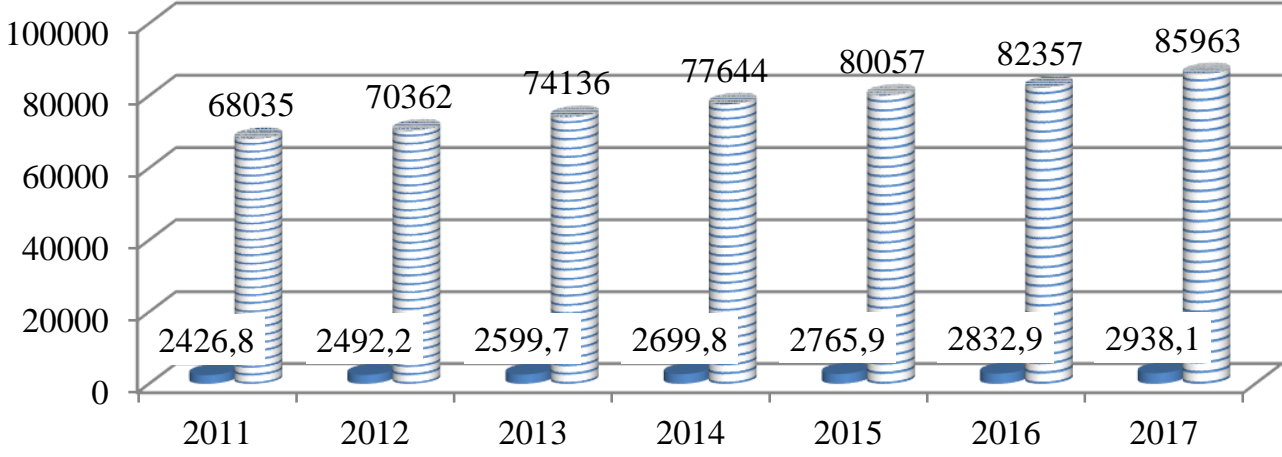

Рис. 8. Динаміка кількості осіб, що знаходяться на диспансерному обліку з приводу онкологічного захворювання за період 2011-2017 pp. (абсолютні значення та в розрахунку на 100 тис. населення)
- Знаходяться на диспансерному обліку на 100 тис. населення м. Києва

- Знаходяться на диспансерному обліку абс. 


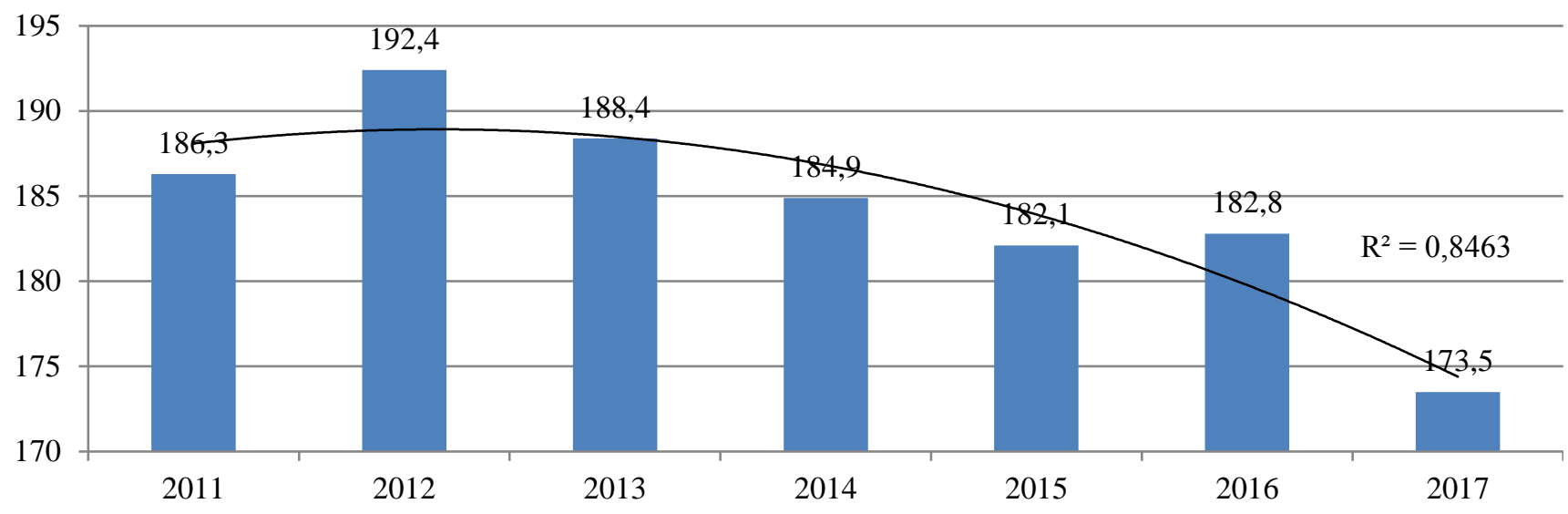

Рис. 9. Динаміка смертності від злоякісних новоутворень за період 2011-2017 pр. (на 100 тис. населення)

Смертність від злоякісних новоутворень зменшилася як серед жінок (з 155,4 в 2011 р. до 141,5 в 2017 р., або -8,94\%), так і серед чоловіків (з 222,4 в 2011 р. до 210,4 в 2017 р., або -5,4\%) (рис. 10).

Найвищі рівні смертності від злоякісних новоутворень серед чоловіків 3 виявленими тенденціями до зростання в 2017 р. зареєстровані в Черкаській (з 236,0 в 2011 р. до 254,3 в 2017 р., або +7,75\%), Вінницькій (з 234,8 в 2011 р. до 247,7 в 2017 р., або $+5,49 \%$ ),
Чернігівській (з 240,9 в 2011 р. до 247,3 в 2017 р., або $+2,66 \%)$ областях. При незначному зменшенні показника в Сумській (з 252,8 в 2011 р. до 251,2 в 2017 р., або -0,63\%) та Кіровоградській (з 253,6 в 2011 р. до 247,0 в 2017 р., або $-2,6 \%$ ) областях, його значення в 2017 р. залишається високим в порівнянні із середньоукраїнським значенням 210,4 на 100 тис. населення та найменшим 147,3 в Одеській області. Різниця між крайніми значеннями показника склала в 1,73 разу $(\mathrm{p}<0,01)$.

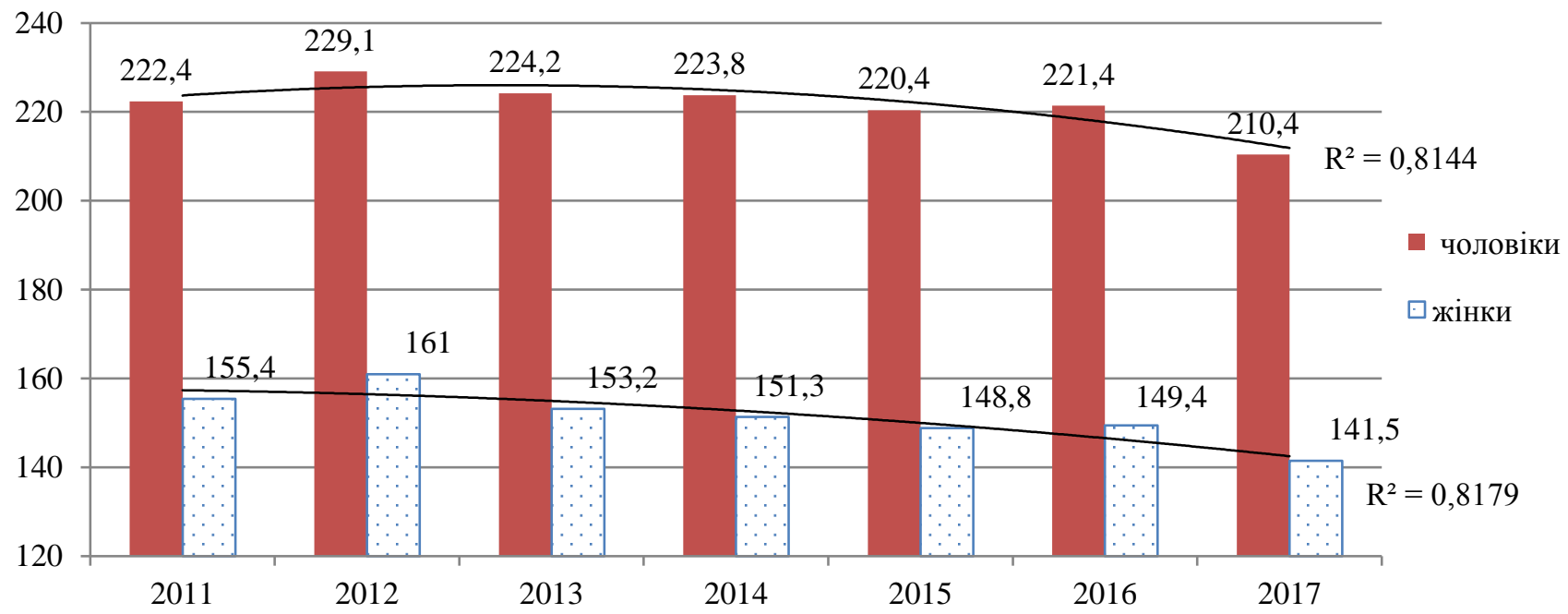

Рис. 10. Динаміка смертності від злоякісних новоутворень чоловіків та жінок за період 2011-2017 pp. (на 100 тис. населення)

Смертність жінок від злоякісних новоутворень за період дослідження зменшилася суттєвіше, ніж серед чоловіків $(-8,94 \%$ серед жінок проти $-5,4 \%$ серед чоловіків). Найвищі значення смертності від онкологічної патології 3 тенденціями до зростання за підсумками 2017 року реєструвалися серед жінок Сумської (з 152,1 в 2011 р. до 168,9 в 2017 р., або +11,05\%), Черкаської (з 143,1 в 2011 р. до 156,9 в 2017 р., або +9,64\%) областей. Незважаючи на помірне зменшення смертності від злоякісних новоутворень серед жінок Дніпропетровської (3 169,4 в 2011 р. до 164,9 в 2017 р., або -2,66\%) та Кіровоградської (з 169,5 в 2011 р. до 163,1 в 2017 р., або $-3,78 \%$ ) областей, виявлені в них значення показника залишаються високими в порівнянні із середнім по Україні - 141,5 на 100 тис. населення. Найменшою смертність від злоякісних новоутворень серед жінок за підсумками 2017 р. виявлена в Закарпатській $(105,0)$ та Волинській $(107,0)$ областях. Різниця між крайніми значеннями показника склала в 1,6 разу $(\mathrm{p}<0,05)$.

В 2017 p. структуру смертності від злоякісних новоутворень у чоловіків формували наступні нозологічні форми. На першому місці як за захворюваністю, так і за смертністю серед чоловіків знаходиться рак трахеї, бронхів, легені (в 2011 р. - 24,3\%, в 2017 р. - 22,5\%). На другому місці залишається рак шлунка (2011 р. - 11,2\%, в 2017 p. $-10,1 \%$ ), на третьому місці із зростанням питомої 
ваги в структурі смертності чоловіків від злоякісних новоутворень опинився рак передміхурової залози (2011 p. - 7,3\%, 2017 p. - 8,7\%). Не дивлячись на те, що у структурі захворюваності чоловіків на злоякісні новоутворення рак прямої кишки у 2011 р. зайняв шосте рангове місце, в структурі смертності від них, рак прямої кишки (6,3\%) посів в 2011 р. четверте, а в 2017 р. 3 тією ж питомою вагою 6,3\% п'яте рангове місце, поступившись при цьому локалізації раку в ободовій кишці $(6,4 \%)$. Рак підшлункової залози як в 2011 р. (5,0\%), так і в 2017 р. (5,3\%) посів шосте місце.

Серед жінок незмінним лідером, як в структурі захворюваності на злоякісні новоутворення, так і в структурі смертності від них, залишається рак молочної залози (в 2011 р. - 20,2\%, в 2017 р. - 20,2\%). На другому місці також незмінно у жінок залишився рак ободової кишки (в 2011 р. - 8,6\%, в 2017 р. - 8,5\%). Третє місце продовжує обіймати рак шлунка (в 2011 р. - 8,6\%, в 2017 р. - 7,7\%), на четвертому - локалізація новоутворення в прямій кишці (в 2011 р. - 6,9\%, в 2017 р. $6,6 \%$ ), на п'ятому місці залишився рак яєчника (в 2011 р. $6,4 \%$, в 2017 p. $-6,3 \%)$.

В структурі смертності чоловіків від злоякісних новоутворень третину $(31,3 \%)$ складає вікова група 5564 роки. Серед причин смертності чоловіків цієї вікової групи переважає локалізація раку в: трахеї, бронхах, легенях (25,1\%); шлунку (10,2\%); простаті (7,4\%); прямій кишці (6,3\%); ободовій кишці (6,3\%). За період 20112017 рр. перелік нозологій, з причини яких виникає смерть у наведеній віковій групі чоловіків практично не змінився (в 2011 р. трахея, бронхи, легені - 26,8\%, шлунок $-11,1 \%$, передміхурова залоза $-6,7 \%$, пряма кишка $-6,2 \%$, ободова кишка $-5,8 \%$ ).

Ще третина $(29,3 \%)$ смертей чоловіків від раку відбувається у віковій групі 65-74 роки, за локалізацією це рак: трахеї, бронхів, легені - 20,3\%, передміхурової залози - 14,7\%, шлунка - 11,8\%, ободової кишки -9,4\%, прямої кишки $-8,8 \%$.

Смертність від злоякісних новоутворень жінок приблизно однаково розподілена за віковими групами: 5564 роки $(25,1 \%) ; 65-74$ роки $(27,4 \%) ; 75$ і старше $(29,2 \%)$, що дозволяє висловити припущення про те, що жінки помирають від раку в більш пізньому віці, можливо за рахунок того, що раніше звертаються за медичною допомогою, а отже $є$ можливість своєчасно і з більшою ефективністю надати медичну допомогу.

В м. Києві смертність від онкологічної патології в цілому за досліджуваний період після незначних коливань (рис. 11) зменшилася (з 164,6 в 2011 р. до 161,6 на 100 тис. населення в 2017 р., або -1,82\%). В 2017 р. від раку померло 4729 осіб, з них 569 від раку легенів (19,4 на 100 тис. населення), 479 - від раку молочної залози $(30,3)$, 396 - ободової кишки $(13,5), 303$ - простати $(22,5), 288$ прямої кишки $(9,8)$.

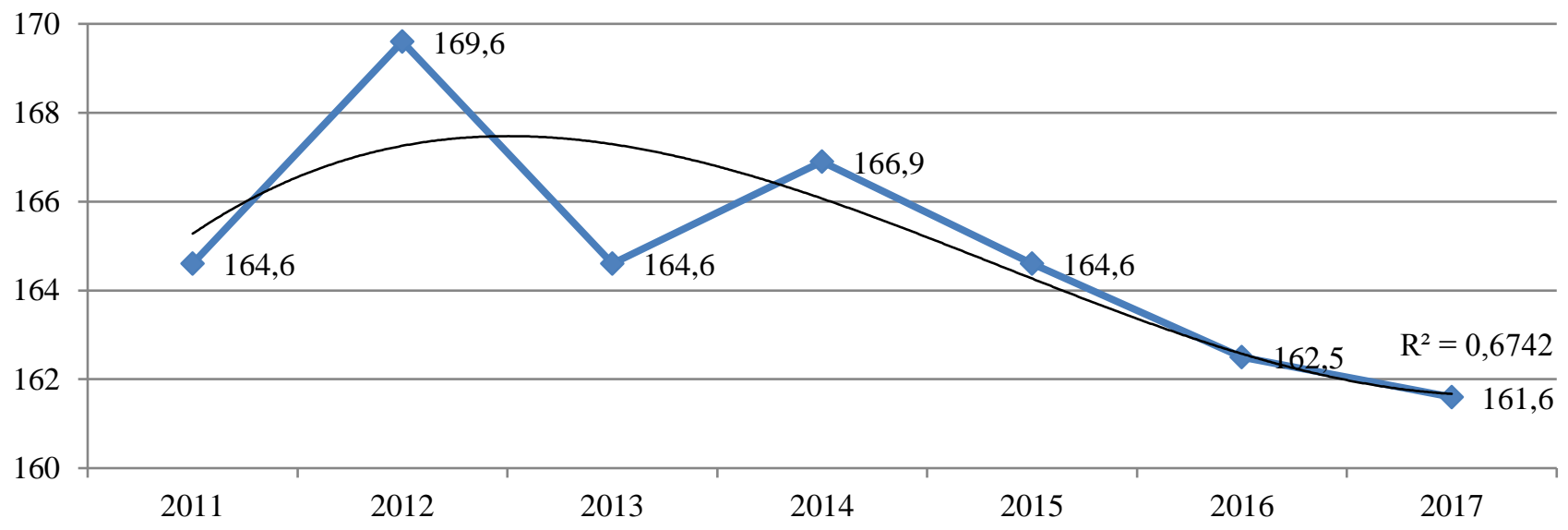

Рис. 11. Динаміка смертності від онкологічної патології за період 2011-2017 pр. (на 100 тис. населення)

Найсуттєвіше зменшення смертності від онкологічної патології за роки дослідження відбулося в Печерському (з 161,2 в 2011 р. до 125,7 на 100 тис. населення в 2017 р., або -22,02\%) та Солом'янському ( 143,8 до 121,1 , або $-15,8 \%$ ) районах столиці. Найвищими iї значення залишаються в Оболонському $(183,6)$, Деснянському $(183,1)$, Дніпровському $(168,7)$ та Святошинському (164,1 на 100 тис. населення) районах столиці із динамікою зростання за період 2011-2017 рр. на $+2,4 \%, 6,52 \%, 2,06 \%$ та $1,42 \%$ відповідно.

Окремо нами вивчалася смертність по причині злоякісного новоутворення прямої кишки, яка за період дослідження зменшилася з 12,3 в 2011 р. до 11,3 на 100 тис. населення в 2017 р., або -8,1\% (рис. 12).
Ще більшими темпами відбулося іiї зменшення в м. Києві (з 12,1 в 2011 р. до 10,0 в 2017 р., або -17,36\%). Високими в 2017 р. залишаються значення показника в Херсонській $(15,4)$, Хмельницькій $(14,4)$ та Сумській (14,2 на 100 тис. населення) областях, при середньому по Україні значенні 11,3 та найменшому значенні показника 7,3 в Івано-Франківській області. Різниця між крайніми значеннями показника склала в 2,1 разу $(\mathrm{p}<0,001)$.

Iз зменшенням відсотку виявлення злоякісних новоутворень прямої кишки під час профілактичних оглядів, зменшується відсоток встановлення діагнозу вперше в I-II стадії захворювання (з 63,6\% в 2011 р. до 56,8 в 2017 р.), 3 одночасним зростанням питомої ваги випадків встановлення вперше раку прямої кишки в пізній 
(IV) стадії захворювання (3 14,9\% в 2011 р. до 17,6\% в 2017 р.). Найвищим відсоток виявлення злоякісного новоутворення прямої кишки в IV стадії захворювання за підсумками 2017 р. виявлено в Волинській (25,8\%), Херсонській $(25,3 \%)$ областях, де найнижчими були виявлені відсотки встановлення діагнозу під час профілактичних обстежень, що доводить доцільність впливу на медико-організаційні фактори формування збільшення відсотку діагностики раку прямої кишки в пізніх його стадіях.

Ситуацію доповнює показник дорічної летальності хворих з раком прямої кишки, який за період дослідження зменшився з 31,1\% в 2011 р. до $27,0 \%$ в 2017 р. (рис. 12), що засвідчує ситуацію, коли кожен третій пацієнт 3 діагнозом раку прямої кишки помирає протягом року 3 моменту встановлення діагнозу.

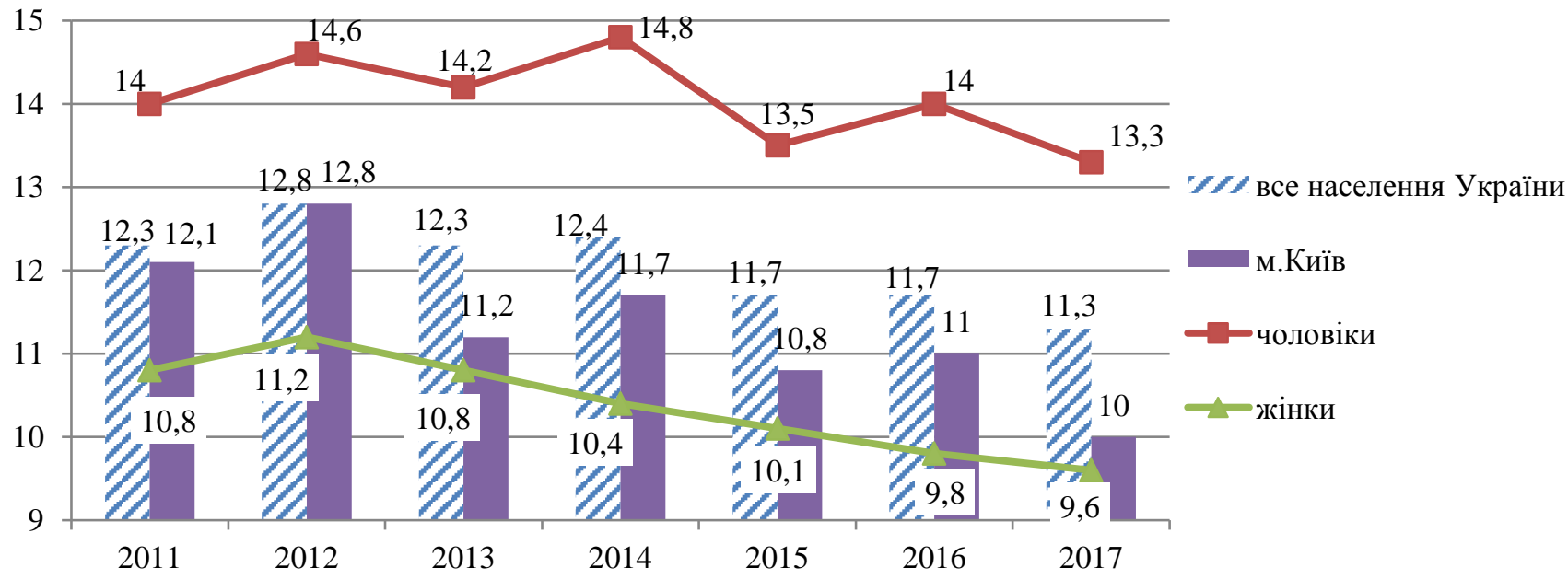

Рис. 12. Динаміка смертності від злоякісного новоутворення прямої кишки за період 2011-2017 pp., на 100 тис. населення

Потребують подальшого вивчення в динаміці виявлені регіональні особливості, що може стати суттєвим інформаційним підгрунтям для формування регіональних програм профілактики злоякісних новоутворень.

\section{Висновки}

При виявлених загальноукраїнських тенденціях до зменшення захворюваності на злоякісні нововутворення в цілому по Україні (з 370,7 в 2011 р. до 354,8 в 2017 р., або $-4,25 \%)$ в структурі захворюваності чоловічого населення на злоякісні новоутворення високою виявлена питома вага локалізації в трахеї, бронхах, легені $(15,8 \%)$, простаті $(10,7 \%)$, шлунку $(7,4 \%)$. Серед жіночого населення переважають локалізації: молочна залоза (20,3\%); тіло матки $(9,1 \%)$; ободова кишка $(6,5 \%)$; шийка матки $(5,9 \%)$. Відсоток вперше встановлення діагнозу онкологічного захворювання у жінок вікової групи $30-54$ роки $(24,9 \%)$ $\epsilon$ вищим від аналогічного у чоловіків $(17,8 \%)$, і навпаки, у віковій групі 55-64 роки він переважає серед чоловіків (30,4\% проти 26,0\%), що може свідчити про пізніше звернення чоловіків за медичною допомогою.

Смертність від злоякісних новоутворень, як в Україні (-6,87\%, до 173,5 в 2017 р.), так і в м. Києві (-2,21\%, до 164,0 на 100 тис. населення в 2017 р.) поступово зменшується. Якщо серед чоловіків смертність від раку характеризується негативною динамікою, як в Україні $(-5,4 \%$, з 222,4 до 210,4), так і в м. Києві (з 189,5 до 180,5, або $-4,75 \%)$, то при негативних тенденціях смертності від раку серед жінок в Україні (з 155,4 до 141,5, або -8,94\%), в м. Києві показнику була властива зворотня тенденція (з 149,1 до 149,7, або +0,4\%). В структурі смертності від злоякісних новоутворень чоловіків перші рангові місця належать локалізацї в трахеї, бронхах, легені (22,5\%), шлунку $(10,1 \%)$, передміхуровій залозі $(8,7 \%)$, серед жінок це: молочна залоза $(20,2 \%)$; ободова кишка $(8,5 \%)$; шлунок $(7,7 \%)$.

Захворюваність на злоякісні новоутворення $(364,8$ серед чоловіків проти 346,1 серед жінок), як і смертність від них (210,4 серед чоловіків проти 141,5 серед жінок) переважає серед чоловіків, за виключенням Київської області та м. Києва, де захворюваність на рак переважає серед жінок $(355,4$ серед чоловіків проти 395,2 серед жінок).

Регіональних розподіл зростаючого контингенту хворих із злоякісними новоутвореннями засвідчив їх накопичення в південному та центральному регіонах країни 3 найвищими за підсумками 2017 р. рівнями в Миколаївській $(3075,7)$, Сумській $(3062,0)$, Київській $(3061,3)$, Черкаській $(3046,7)$ областях та м. Києві $(2980,2$ на 100 тис. населення). Суттєво переважає зростаюча кількість жіночого контингенту (з 2686,7 до 3183,5, або $+18,5 \%$ ) проти зростаючого, але порівняно меншими темпами контингенту чоловіків із злоякісними новоутвореннями (з 1690,6 до 1976,0, або +16,9\%).

Одночасно із зменшенням відсотку виявлення злоякісних новоутворень під час профілактичних оглядів (з $29,7 \%$ до $28,0 \%$, або $-5,7 \%$ ) 3 найвищими значеннями показника в м. Києві (з 64,8\% до 58,3\%, або -10,0\%), в Україні зростає відсоток встановлення вперше діанозу 
злоякісного новоутворення в занедбаній (IV) стадії захворювання (з 14,7\% до $17,0 \%$, або $+15,6 \%$ ) при $7,7 \%$ в м. Києві.

Рак прямої кишки в структурі захворюваності, як серед чоловіків, так і сред жінок, посідає незмінно шосте рангове місце, в структурі смертності, 3 незмінною питомою вагою 6,3\% - п'яте рангове місце. Попри зменшення захворюваності $(-6,3 \%)$ та смертності $(-8,1 \%)$, контингент хворих на рак цієї локалізації зростає $(+18,2$, 3 незначним переважанням чоловіків (120,1 проти 115,2 серед жінок). Одночасно зменшується дорічна летальність пацієнтів з раком цієї локалізації (до 27,\% в 2017 р.), зменшується відсоток встановлення діагнозу в ранній III ст. захворювання (з 63,6\% до 56,8\%) та зростає відсоток виявлення патології в пізній (IV) його стадії (з 14,9 до $17,6 \%)$.

\section{Література}

1. American Cancer Society. Cancer Facts \& Figures 2011. Atlanta: ACS, 2011. -24 p.

2. Bartram J. Flowing away: water and health opportunities / J. Bartram // Bull World Health Organ. - 2008. Vol. 86. - P 277-279. doi:10.2471/BLT.07.049619 PMID:18235877.

3. Commission on Social Determinants of Health. Closing the gap in a generation: health equity through action on the social determinants of health. Final report of the Commission on Social Determinants of Health. Geneva, World Health Organization, 2008 [Електронний ресурс]. - Режим доступу: http://www.who.int/social_determinants/final_report/en/ index.html.

4. Comparison of fracture risk prediction by the US Preventive Services Task Force strategy and two alternative strategies in women 50-64 years old in the Women's Health Initiative / C. J. Crandall, J. C. Larson, N. B. Watts, M. L. Gourlay [et al.] // J. Clin. Endocrinol. Metab. - 2014. - Vol. 99 (12). - P. 4514-4522. doi:10.1210/jc. 2014-2332.

5. Diagnosis and treatment of melanoma: European consensus-based interdisciplinary guideline / C. Garbe, K. Peris, A.Hauschild [et al.] // European Journal of Cancer. - 2010. - Vol. 46. - P. 270-283.

6. National health accounts [online database]. Geneva, World Health Organization, 2010 [Електронний ресурс]. Режим доступу: http://www.who.int/nha,accessed 23 June 2010. - Назва з екрана.

7. Opportunities for cancer prevention during midlife: highlights from a meeting of experts / D. M. Holman, M. Grossman, S. J. Henley, L. A. Peipins, L. Tison, M. C. White // Am. J. Prev. Med. - 2014. - Vol. 46 (3 Suppl 1). P. S73-80. doi: 10.1016/j.amepre.2013.10.030.

8. Шафранський В. В. Основи Європейської політики і стратегія для XXI століття: стратегічне керівництво в інтересах здоров’я / В. В. Шафранський, Г. О. Слабкий, Л. О. Качала // Економіка і право охорони здоров’я. - 2016. № 2 (4). - С. 72-75.

9. Трагедія, якої можна уникнути: подолання в Україні кризи здоров’я людей // Світовий банк. $-2010 .-16$ с.

10. Регіональні особливості стану здоров'я населення України (за період 2005-2009 рр.) / Слабкий Г. О., Медведовська Н. В. // Монографія: Київ, 2010. - 174 с.

11. Mathers C.D. Projections of global mortality and burden of disease from 2002 to 2030 / C.D. Mathers, D. Loncar // PLoS Med. - 2006. - Vol. 3. - P. 442. doi:10.1371/journal. pmed.003004422 PMID:17132052.

\section{References}

1. American Cancer Society. Cancer Facts \& Figures 2011. Atlanta: ACS, 2011. -24 p.

2. Bartram J. Flowing away: water and health opportunities / J. Bartram // Bull World Health Organ. - 2008. Vol. 86. - P 277-279. doi:10.2471/BLT.07.049619 PMID:18235877.

3. Commission on Social Determinants of Health. Closing the gap in a generation: health equity through action on the social determinants of health. Final report of the Commission on Social Determinants of Health. Geneva, World Health Organization, 2008 [Elektronnyy resurs]. - Rezhym dostupu: http://www.who.int/social_determinants/final_report/en/ index.html.

4. Comparison of fracture risk prediction by the US Preventive Services Task Force strategy and two alternative strategies in women 50-64 years old in the Women"s Health Initiative / C. J. Crandall, J. C. Larson, N. B. Watts, M. L. Gourlay [et al.] // J. Clin. Endocrinol. Metab. - 2014. - Vol. 99 (12). - P. 4514-4522. doi:10.1210/jc. 2014-2332.

5. Diagnosis and treatment of melanoma: European consensus-based interdisciplinary guideline / C. Garbe, K. Peris, A.Hauschild [et al.] // European Journal of Cancer. - 2010. - Vol. 46. - P. 270-283.

6. National health accounts [online database]. Geneva, World Health Organization, 2010 [Elektronnyy resurs]. Rezhym dostupu: http://www.who.int/nha,accessed 23 June 2010. - Nazva z ekrana.

7. Opportunities for cancer prevention during midlife: highlights from a meeting of experts / D. M. Holman, M. Grossman, S. J. Henley, L. A. Peipins, L. Tison, M. C. White // Am. J. Prev. Med. - 2014. - Vol. 46 (3 Suppl 1). P. S73-80. doi: 10.1016/j.amepre.2013.10.030. 
8. Shafrans'kyy V. V. Osnovy Yevropeys'koyi polityky i stratehiya dlya KHKHI stolittya: stratehichne kerivnytstvo v interesakh zdorov"ya / V. V. Shafrans'kyy, H. O. Slabkyy, L. O. Kachala // Ekonomika i pravo okhorony zdorov"ya. 2016. - № 2 (4). - S. 72-75. $16 \mathrm{~s}$.

9. Trahediya, yakoyi mozhna unyknuty: podolannya v Ukrayini kryzy zdorov"ya lyudey // Svitovyy bank. - 2010. -

10. Rehional'ni osoblyvosti stanu zdorov"ya naselennya Ukrayiny (za period 2005-2009 rr.) / Slabkyy H. O., Medvedovs'ka N. V. // Monohrafiya: Kyyiv, 2010. - 174 s.

11. Mathers C.D. Projections of global mortality and burden of disease from 2002 to 2030 / C.D. Mathers, D. Loncar // PLoS Med. - 2006. - Vol. 3. - P. 442. doi:10.1371/journal. pmed.003004422 PMID:17132052.

Дата надходження рукопису до редакції: 12.05.2020 p.

В публікації наведено результати вивчення показників смертності, захворюваності на злоякісні новоутворення серед різних статево-вікових груп населення України та м. Києва, як прикладу мегаполісу в Україні (в розрізі основних адміністративних територій (районів) на основі проведення аналізу даних офіційної статистики.

Метою дослідження стало вивчення регіональних, статевих і вікових особливостей показників смертності, захворюваності на злоякісні новоутворення, тенденцій їх динаміки серед населення України на основі проведення аналізу даних офіційної статистики в порівнянні з попередньо описаними в наукових публікаціях тенденціями.

Матеріалами для дослідження слугували дані офіційної статистичної звітності закладів охорони здоров'я областей України та районів міста Києва. В дослідженні були використані класичні методи соціальної медицини, а саме бібліосемантичний, медико-статистичний, аналітико-синтетичний та контент-аналізу.

За результатами проведеного за період 2011-2017 pp. дослідження були виявлені області України 3 високими рівнями смертності, захворюваності на рак у різних вікових групах чоловіків і жінок. Доведено, що сформовані тенденції смертності та захворюваності на злоякісні новоутворення серед населення міста Києва, в цілому відповідають загальноукраїнським, проте мають суттєві особливості.

У висновках обгрунтовано потребу подальшого вивчення в динаміці виявлених регіональних та статево-вікових особливостей показників смертності, захворюваності на злоякісні новоутворення в розрізі областей України та в м. Києві для з'ясування ймовірних медико-організаційних причин їх формування та обгрунтування доцільності формування регіональних програм профілактики злоякісних новоутворень, зокрема на прикладі попередження розвитку раку з локалізацією в прямій кишці.

Ключові слова: смертність, захворюваність на злоякісні новоутворення, регіональні особливості, місто Київ.

В публикации приведены результаты изучения показателей смертности, заболеваемости злокачественными новообразованиями в разных поло-возрастных группах населения Украины и города Киева, как примера мегаполиса в Украине (в разрезе основных административных территорий (районов) на основе проведения анализа данных официальной статистики.

Целью исследования стало изучение региональных, половых и возрастных особенностей показателей смертности, заболеваемости злокачественными новообразованиями, тенденций их динамики среди населения Украины на основе проведения анализа данных официальной статистики в сравнении с предварительно описанными в научных публикациях тенденциями.

Материалами для исследования послужили данные официальной статистической отчетности учреждений здравоохранения областей Украины и районов города Киева. В исследовании были использованы классические методы социальной медицины, а именно библиосемантический, медико-статистический, аналитико-синтетический и контентанализа.

По результатам проведенного за период 2011-2017 гг. исследования были выявлены области Украины с высокими уровнями смертности, заболеваемости раком в разных возрастных группах мужчин и женщин. Доказано, что сформированные тенденции смертности и заболеваемости злокачественными новообразованиями среди населения города Киева, в целом соответствуют среднеукраинским, хотя имеют существенные особенности.

В выводах обосновано потребность дальнейшего изучения в динамике выявленных региональных и половозрастных особенностей смертности, заболеваемости злокачественными новообразованиями в разрезе областей Украины и в городе Киеве, с целью наличия вероятных медико-организационных причин их формирования и обоснования целесообразности формирования региональных программ профилактики злокачественных новообразований, в частности на примере предупреждения развития рака с локализацией в прямой кишке.

Ключевые слова: смертность, заболеваемость злокачественными новообразованиями, региональные особенности, город Киев. 
In the publication results of studying of indicators of mortality, incidence of malignant new growths are given in different gender and age groups of the population of Ukraine and the city of Kyiv as example of the megalopolis in Ukraine (in a section of the main administrative territories (areas) on the basis of carrying out the analysis of data of official statistics.

Studying of regional, sexual and age features of indicators of mortality, incidence of malignant new growths, tendencies of their dynamics among the population of Ukraine on the basis of carrying out the analysis of data of official statistics in comparison with the tendencies which are previously described in scientific publications became a research objective.

Have served as materials for a research given to the official statistical reporting of healthcare institutions of the areas of Ukraine and districts of the city of Kyiv. In a research classical methods of social medicine, namely bibliosemanticaly, medicostatistical, analytyko-synthetic and the content analysis have been used. Behind results of the research conducted during 20112017 the areas of Ukraine with high death rates, cancer cases in different age groups of men and women have been revealed. It is proved that the created tendencies of mortality and incidence of malignant new growths among the population of the city of Kyiv, in general correspond medium in Ukraine though have essential features. In conclusions it is proved the need of further studying for dynamics of the revealed regional and gender and age features of mortality, incidence of malignant new growths for a section of the areas of Ukraine and for the city of Kyiv, for the purpose of existence of the probable medico-organizational causes of their formation and justification of expediency of formation of regional programs of prevention of malignant new growths, in particular on the example of prevention of development of cancer with localization in a rectum.

Key words: mortality, incidence of malignant new growths, regional features, city of Kyiv.

\section{Відомості про автора}

Клюсов Олександр Миколайович - директор Київського міського клінічного онкологічного центру, аспірант кафедри управління охороною здоров’я НМАПО імені П.Л. Шупика; 04112 вул. Дорогожицька, 9, м. Київ, Україна. +380 (66) 273-17-73, kmkoc.kyiv@ gmail.com, ORCID ID 0000-0003-3642-2515. 